\title{
Does the IASB know the needs of SMEs? A comparative analysis between the IFRS for SMEs and full IFRS due processes
}

\author{
Rafael Bautista-Mesa ${ }^{a}$, Juan María Muñoz-Tomás ${ }^{\mathrm{b}}$, María Paz Horno-Bueno ${ }^{\mathrm{c}}$ \\ a) b) Accounting and Finance Department, Universidad Loyola Andalucía, Córdoba, Spain \\ c) Accounting and Finance Department, University of Jaén, Jaén, Spain
}

${ }^{a}$ Corresponding author.

E-mail address: rbautista@uloyola.es

\section{A R T I C L E IN F O}

\section{Article history:}

Received 2 August 2018

Accepted 6 Feb 2019

Available online 1 July 2019

\section{JEL classification:}

M480

Keywords:

IFRS for SMEs

Lobbying

IASB

Due process

Developing countries

\section{A B S T R A C T}

Our research contributes to the limited literature on lobbying in accounting standards for SMEs by analysing all comment letters in the due process for the IFRS for SMEs (from 2004 to 2012) and comparing them to all of the 97 IASB's projects related to full IFRS during the same period of time. Results confirm that the participation of preparers is significantly lower in the international accounting standardisation process for SMEs. Although this reduced participation is compensated by a higher participation of auditors, results also reveal that auditors do not match the interests of preparers in the case of the IFRS for SMEs. In conclusion, the IASB finds a limitation of the Institutional Theory (Meyer and Rowan, 1977) in the case of the IFRS for SMEs, drawing attention to the need of IASB for conducting further analysis about the real preferences, not only of specific users of the SMEs' financial information, but also of SMEs. We finally suggest the relevance of the analysis of the needs of SMEs in developing countries, in line with the pronouncements of UNCTAD (2003).

(C)2019 ASEPUC. Published by EDITUM - Universidad de Murcia. This is an open access article under the CC BY-NC-ND license (http://creativecommons.org/licenses/by-nc-nd/4.0/).

¿Conoce el IASB las necesidades de las PYMES? Un análisis comparativo de los procesos debidos de la NIIF para las PYMES y de las NIIF completas

R E S U M E N

Nuestra investigación contribuye a la reducida literatura sobre 'lobbying' en la NIIF para las PYMES al analizar todas las cartas de comentario en el 'due process' (entre 2004 y 2012) y compararlas con los 97 proyectos las NIIF completas relacionados con las NIIF completas durante el mismo período de tiempo. Los resultados confirman que la participación de los preparadores es significativamente menor en el proceso de normalización contable internacional para las PYMES. Si bien esta participación reducida se ve compensada por una mayor participación de los auditores, los resultados también revelan que los auditores no coinciden con los intereses de los preparadores en el caso de las NIIF para las PYMES. En conclusión, el IASB encuentra una limitación de la Teoría Institucional (Meyer y Rowan, 1977) en el caso de la NIIF para las PYMES, llamando la atención sobre la necesidad de que el IASB realice análisis adicionales sobre las necesidades reales, no solo de usuarios específicos de la información financiera emitida por las PYMES, sino también de las propias PYMES. Finalmente, sugerimos análisis adicionales de las necesidades de las PYMES en los países en desarrollo, en línea con los pronunciamientos de la UNCTAD (2003).

(C)2019 ASEPUC. Publicado por EDITUM - Universidad de Murcia. Este es un artículo Open Access bajo la licencia CC BY-NC-ND (http://creativecommons.org/licenses/by-nc-nd/4.0/). 


\section{Introduction}

Economic globalization has resulted in the transfer of certain regulatory decisions to international institutions with a technocratic nature. Some of them are publicly funded, such as the Bank for International Settlements while others are also funded by private stakeholders, such as the International Accounting Standards Board (IASB). Small and Medium-sized Entities (SMEs), with fewer resources, may be forced to exert greater efforts in order to ensure their representation within these new institutions.

It is commonly argued the economic importance that SMEs represent globally: over $99 \%$ of the entities in the world are SMEs (Vasek, 2011), while only 46,000 companies are listed in the 52 largest stock exchanges in the world (IASB, 2016). Then, in the increasingly global economy, a unique set of financial reporting standards seems to be necessary that provide comparable high-quality financial information for these entities (Pacter, 2009; Devi and Samujh, 2015). Therefore, international comparability in financial reporting could be achieved with the adoption of globally accepted standards not only by listed entities, but also by SMEs, financial institutions, auditors, etc. (Klç et al., 2014).

The IASB issued the International Financial Information Standard for entities that do not have public accountability (unlisted companies) in 2009 (hereinafter IFRS for Small and Medium-sized Entities or IFRS for SMEs), a simplified version of the full IFRS with significantly reduced recognition and measurement principles, and disclosure requirements. According to the IASB, the IFRS for SMEs would reflect the specific needs of external users of SMEs' financial information, as well as the cost-benefit considerations of SMEs (IASB, 2009b).

Nearly a decade after its issuance, while 86 jurisdictions have adopted or permitted the use of IFRS for SMEs, most of which are developing countries (Bonito and Pais, 2018), the IFRS for SMEs is not used or under consideration in 69 jurisdictions (IASB, 2018). Previous research has confirmed the existence of institutional factors against the implementation of the IFRS for SMEs (Kaya and Koch, 2014). For example, the European Union remains against its use due to its inconsistencies with the European accounting directive (Bonito and Pais, 2018). Moreover, the simplification based on the same conceptual framework of the full IFRS and the extent to which it fulfills the information needs of the users of SMEs financial information remain unclear (Perera and Chand, 2015), which is what makes the IFRS for SMEs worthy of further research.

The due process, formerly designed according to the resources and capabilities of listed companies to issue full IFRS, allows stakeholders to participate in the standard-setting process (IFRS Foundation, 2013a; 2013b), and is aimed to enhance IASB's input legitimacy (Richardson and Eberlyn, 2011). As a way of 'mimetic isomorphism' in the terms defined by DiMaggio and Powell (1983) according to the Institutional Theory (Meyer and Rowan, 1977), the IASB used the due process to issue the IFRS for SMEs. Thus, the IASB may have not taken into consideration the preferences of unlisted companies, or SMEs according to the final denomination of the IFRS for SMEs.

Our research aims to confirm whether the preferences of SMEs were adequately represented in the IFRS for SMEs due process. Special analysis is also devoted to developing economies where there is more limited access to capital markets, in accordance with the recommendations of the United Nations Conference on Trade and Development
(UNCTAD, 2003). To achieve this, we first identify the groups of stakeholders among constituents, something that previous research has only studied in the context of full IFRS. Then, we explore the key differences between the due process of both sets of standards, by comparing comment letters in the IFRS for SMEs due process from 2004 to 2012 with all of the full IFRS projects (97) issued during the same period of time.

The results reveal some relevant differences with full IFRS Preparers participate according to a common interest that differs from that of other groups, including auditors, and in a lower proportion than in the case of full IFRS. This suggests greater difficulties of SMEs to express their views to the IASB. Thus, we highlight the need for further analysis of the real preferences, not only of users of SMEs' financial information (Devi and Samujh, 2015), but also of SMEs themselves. We suggest that efforts must still be made to adapt the IFRS for SMEs to the real preferences of SMEs, especially in developing economies.

The study begins with an introduction to the theoretical framework on which extant research is based with respect to lobbying on accounting regulation. This framework justifies the development of our research questions. Sections 3 and 4, respectively, present the methodology followed and the main results obtained. Finally, the paper concludes by drawing its main conclusions.

\section{Theoretical framework and development of research questions}

The IASB's objective of introducing a new accounting regulatory framework for SMEs was two-fold: on the one side, reducing the administrative burden of SMEs; on the other, providing relevant and useful accounting data to aid the decision-making process of the 'external users' of accounting information (IASB, 2009b).

Thus, the first singularity of the accounting regulatory framework for SMEs recognized by the IASB was the lower capability of preparers. However, cost burdens on SMEs are still perceived to be the most important disadvantages of moving from local GAAP to IFRS for SMEs. Costs of the implementation (including costs of training, new accounting software, information system changes, the need for consulting services, etc.) may exceed its benefits (Klç et al., 2014; Klç and Uyar, 2017). SMEs are supposed to continue preparing financial statements for tax purposes, so they will afford costs relating to the application of dual reporting (Ballas et al., 2010). Moreover, most of the managerial decisions of the SMEs take other internal information into consideration (Moneva and Cuéllar, 1998; Milanés and Texeira, 2006).

The second singularity recognised by the IASB consists of the existence of differences in the nature of 'external users' of financial information. Some research states that the Government is the main user of the financial statements of the SMEs because of tax and regulation purposes (Milanés and Texeira, 2006), while other users are skeptical about the reliability of accounting information (Albu et al., 2010). However, the IASB does not actually recognize as users of the IFRS for SMEs those who are in the position to require tailored reports to meet their information needs, i.e., supervisors of laws and regulations, as well as shareholders (IASB, 2019a). Thus, the IFRS for SMEs focuses on the information needs of lenders, creditors, and other users of SME financial statements who are primarily interested in information about cash flows, liquidity, and solvency (IASB, 2009b). This represents a paradigm shift from the traditional objective of financial reporting of SMEs drawn from the concept of 'user oriented 
financial information' (Perera and Chand, 2015). Moreover, there seems to be no agreement among extant research regarding what are the real users and their information needs of SME financial statements (Son et al., 2006).

Besides that, the IASB (2009a) considered that a harmonized and high-quality financial information framework would improve the comparability of financial information of SMEs globally, which would enhance SMEs' access to international financial sources (Berger and Udell, 2004; Allee and Yohn, 2009; Chand et al., 2015). This argument is commonly accepted by extant research on standards for listed companies, as adopting the IFRS seems to improve the opportunities and conditions to obtain local (Kim et al., 2011) and cross-border financial assistance and trade (Ball, 2006; Ballas et al., 2010). However, the number of SMEs engaged in international financial and trade activities seems to be low (Eierle et al. 2011).

\section{Lobbying on the IFRS for SMEs: singularities in stakeholders' behaviour}

It has been traditionally argued that the regulatory process is the result of competition between different interest groups (Becker, 1983). Under the Economic Theory of Democracy, it is commonly accepted that lobbying in accounting regulation is exercised by stakeholders motivated by their own cost-benefit interests (Sutton, 1984; Tandy and Wilburn, 1996). Thus, most influential stakeholders act under the expectation of gaining the added value resulting from the economic consequences of accounting standards (Carmo et al., 2014), according to the Positive Accounting Theory (Watts and Zimmerman, 1978; Dhaliwal, 1982; Seamann, 2004; Zeff, 2008).

However, current research on accounting regulation has been mainly performed only for standards for listed companies. It has been widely stated that stakeholders show a common position with respect to accounting standards according to their role in the financial reporting chain (preparers, users, auditors, standard setters, etc.) (Kelly, 1985; Kenny and Larson, 1993; Seamann, 2004; Hartwig, 2013). The Agency Theory (Jensen and Meckling, 1976) would explain different motivations between preparers and those not preparing financial information (the principal and the agent, respectively), because they possess different interests. While preparers are usually motivated by the economic consequences of the standards (Stenka and Taylor, 2010; Chircop and Kiosse, 2015), the other participants may also be influenced by the usefulness, relevance, and reliability of financial information (Seamann, 2004). Then, unlike standards setters and big audit firms, preparers are not found as recurrent participants in the accounting regulation process, as they are mainly motivated only by standards that have direct economic consequences for themselves (Molina and BautistaMesa, 2018).

In the case of unlisted companies, only very few references exist about the behaviour of stakeholders in the due process. Anacoreta and Duarte (2005) analyse the comment letters sent to the IASB's Discussion Paper in 2004. Unlike our research, they do not take into account the group of the stakeholders. They mainly study the differences between those constituents who have an opinion and those who do not seem to have formed any opinion about the issues raised. Schiebel (2008) does analyse the very early discussion papers between 2004 and 2005 from the perspective of the participation of different groups of stakeholders. The author highlights the IASB's lack of consideration regarding the needs of external users of financial information, finding a minority of letters from this group. Recently, Haveroth et al. (2017) also analyse the characteristics and perspectives of different groups of stakeholders about the IFRS for SMEs, although only considering the IASB's Exposure Draft issued in 2013 to include the first amendments to the IFRS for SMEs after its implementation. Unlike studies by Schiebel (2008) and Haveroth et al. (2017), our research widens the sample by including relevant IASB's drafts, such as the Exposure Draft in 2007 and the Request for Information in 2012. This becomes especially relevant for our study, as previous research has demonstrated differences in the behaviour of stakeholders among the regulatory process. Thus, while the participation of auditors, standards setters and academics is focused on the earliest stages of the process (requests for information and discussion papers), preparers are more concentrated in the final stages (exposure drafts) (Jorissen et al., 2010).

In addition, previous research about lobbying on the IFRS for SMEs has not yet identified common patterns of responses among groups of stakeholders. This analysis is crucial in order to legitimize subsequent research on the behaviour of different groups of stakeholders in the IFRS for SMEs, so this leads us to the first research question:

RQ.1. In the IFRS for SMEs due process, is there a pattern of responses depending on the constituent's role in the financial information chain?

Our work follows questioning whether the singularities of the stakeholders of the IFRS for SMEs give rise to differences with full IFRS due process, in terms of the group of the stakeholders.

First, a lower participation of preparers, i.e., SMEs, is analysed. It is stated that preparers, those most affected by economic consequences of the standard, show a greater presence in the due process for standards for listed companies (Sutton, 1984; Giner and Arce, 2012; Holder et al., 2013; Jorissen et al., 2013). Three factors influence the participation of preparers in the IASB's due process: (i) the size, as larger entities exhibit a greater participation than smaller ones (Sutton, 1984; Francis, 1987; Kenny and Larson, 1993; Jorissen et al., 2010; Hartwig, 2013). Georgiou (2005) expressly showed that the number of comment letters was greater among listed companies than among unlisted ones. (ii) The difficulties of SMEs in making associations of interest by applying Olson's logic of collective action (Olson, 1965). According to this theory, individuals tend to leave others to pay the costs of a collective action that benefits individuals, considering that the action will be carried out even without their participation. Lindahl (1987) applies this theory to the issuance of accounting standards and indicates that association in the response is more likely to occur in standards that affect specific industries. Therefore, a standard, such as the IFRS for SMEs, which is not directed toward any specific industry, should not favor preparers' participation through the association of constituents. (iii) The incipient nature of SME regulation, as well as the uncertainty of its future implementation, may result in a lower number of comment letters. In this sense, Kenny and Larson (1993) justify the lower participation of multinational corporations in the due process of the original IAS 31 for two reasons: the novelty of the new public consultation process established by the IASC in 1989, and the lack of perception on the part of stakeholders about the international legitimacy of this organism. Moreover, according to Holder et al. (2013), participation from countries where the use of the IFRS is mandatory, or at least allowed, is significantly greater than in those countries under local standards. This fact reinforces the idea that during the IFRS for SMEs due 
process, there was a very high uncertainty about what jurisdictions would finally adopt this standard, which might have influenced constituents' behaviour.

The global economic relevance of SMEs has been traditionally remarked by the IASB to argue for the issuance of an international standard for SMEs, as 95\% of the entities around the world are electable for the IFRS for SMEs (IASB, 2016). However, this computation includes a very large number of micro-entities that have no international relevance. Unlike large- and medium-sized entities, small and microenterprises seem to be divided on the benefits that the IFRS for SMEs implies (Internal Market and Services DG, 2010). In the European Union, there is a general opinion to simplify the accounting requirements, especially for the smallest SME (European Commission, 2011). Thus, Directive 2012/6/EU of the European Parliament and of the Council, of 14 March 2012, even introduced a new category of entities with a dimension smaller than micro-enterprises, called micro-entities, which are supposed to operate at the local or regional level and not to carry out cross-border operations in a generalized manner. The aforementioned directive recognizes the excessive burdens for micro-entities and reduces their accounting requirements.

The above reasons would justify a lower participation of preparers in the IRFS for SMEs due process. This then leads us to the second research question:

RQ.2. Is the proportional participation of preparers lower in the due process for the IFRS for SMEs than for full IFRS?

Secondly, we suggest a higher participation of auditors in the IFRS for SMEs due process. On the one hand, costbenefits terms as defined by Sutton (1984) may encourage SMEs to leave their representation in their auditors' hands (Walker and Robinson, 1993; Georgiou, 2002). This would be supported by the Coalition and Influence Group of researchers according to Durocher et al. (2007), which states potential coalitions among different groups of stakeholders looking at their influence on the standard setter's decisions. One of the biggest disadvantages detected after the implementation of the IFRS for SMEs may also support this behaviour by preparers during the regulatory process, i.e., the lack of knowledge and trained personnel to understand the standard (Klç and Uyar, 2017).

Auditors are supposed to play a vital role in the application of the IFRS for SMEs. One of the most critical obstacles to the implementation of the IFRS for SMEs is the lack of accounting training due to the complexity of the standard (Kaya and Koch, 2014). Auditors may also see the possibility of increasing their business in the terms defined by Puro (1984), due to the high quantitative impact of the IFRS for SME in terms of the number of 'clients' affected. In this vein, previous literature has shown that auditors also find an incentive in participating by aligning themselves with the interests of their clients (Haring, 1979; Puro, 1984 and 1985; Mackee et al., 1991). This trend has only been contradicted in the case of the biggest audit firms because of their increasingly oligopolistic situation in the last decades (Allen et al., 2012).

Given the greater number of SMEs and, therefore, auditors 'affected' by this standard, we wonder if these incentives lead to a greater participation of auditors in the IFRS for SMEs due process. This then leads us to the third research question:

RQ.3. Is the proportional participation of auditors higher in the due process for the IFRS for SMEs than for full IFRS?
Geographical singularities of the IFRS for SMEs: special considerations of developing countries

From a geographical perspective, some research has revealed differences in the distribution of participants in the regulatory accounting process, depending on constituents' origin (MacArthur, 1996 and 1999; Larson and Herz, 2013; Jorissen et al., 2006 and 2013). Geographical diversity in the development of IFRS is desirable since it reduces criticism and improves consistency in subsequent applications of the standards (Larson and Herz, 2013; Jorissen et al., 2013).

Table 1

IASB's due process documents regarding IFRS for SMEs

\begin{tabular}{|c|c|c|c|c|}
\hline $\begin{array}{l}\text { Type of } \\
\text { document }\end{array}$ & $\begin{array}{l}\text { Date of } \\
\text { issuance }\end{array}$ & Title & $\begin{array}{l}\text { Deadline } \\
\text { for } \\
\text { receiving } \\
\text { comments }\end{array}$ & $\begin{array}{c}\text { Number of } \\
\text { comment } \\
\text { letters }\end{array}$ \\
\hline Discussion & & Preliminary Views on & & \\
\hline $\begin{array}{l}\text { Discussion } \\
\text { paper }\end{array}$ & June 2004 & $\begin{array}{l}\text { Accounting Standards for Small } \\
\text { and Medium-sized Entities }\end{array}$ & r 24,2004 & 121 \\
\hline $\begin{array}{l}\text { Staff } \\
\text { question- } \\
\text { naire }\end{array}$ & April 2005 & $\begin{array}{l}\text { Staff Questionnaire on Possible } \\
\text { Recognition and Measurement } \\
\text { Modifications for Small and } \\
\text { Medium-sized Entities (SMEs) }\end{array}$ & $\begin{array}{l}\text { May 31, } \\
2005\end{array}$ & 99 \\
\hline $\begin{array}{l}\text { Exposure } \\
\text { draft }\end{array}$ & $\begin{array}{l}\text { February } \\
2007\end{array}$ & $\begin{array}{l}\text { IFRS for Small and Medium- } \\
\text { sized Entities } \\
\text { IFRS for SMEs Section 1, Issue } 1 .\end{array}$ & $\begin{array}{l}\text { October } 1, \\
2007\end{array}$ & 158 \\
\hline $\begin{array}{l}\text { Draft } \\
\text { Q\&A*1 }\end{array}$ & $\begin{array}{c}\text { February } \\
2011\end{array}$ & $\begin{array}{l}\text { Use of the IFRS for SMEs in } \\
\text { parent's separate financial } \\
\text { statements }\end{array}$ & $\begin{array}{l}\text { April 4, } \\
2011\end{array}$ & 16 \\
\hline $\begin{array}{l}\text { Draft } \\
\text { Q\&A*2 }\end{array}$ & April 2011 & $\begin{array}{l}\text { IFRS for SMEs Section 1, Issue } 2 . \\
\text { Captive insurance subsidiaries }\end{array}$ & $\begin{array}{l}\text { June 15, } \\
2011\end{array}$ & 13 \\
\hline $\begin{array}{l}\text { Draft } \\
\text { Q\&A*3 }\end{array}$ & April 2011 & $\begin{array}{l}\text { IFRS for SMEs Section 1, Issue } 3 . \\
\text { Interpretation of 'traded in a } \\
\text { public market' }\end{array}$ & $\begin{array}{l}\text { Jun } 15 \text {, } \\
2011\end{array}$ & 15 \\
\hline $\begin{array}{l}\text { Draft } \\
Q \& A^{*} 4\end{array}$ & April 2011 & $\begin{array}{l}\text { IFRS for SMEs Section 1, Issue } 4 . \\
\text { Investment funds with only a } \\
\text { few participants }\end{array}$ & $\begin{array}{l}\text { June } 15, \\
2011\end{array}$ & 15 \\
\hline $\begin{array}{l}\text { Draft } \\
\text { Q\&A* } 5\end{array}$ & $\begin{array}{l}\text { September } \\
\quad 2011\end{array}$ & $\begin{array}{l}\text { IFRS for SMEs General, Issue } 1 . \\
\text { Application of the IFRS for SMEs } \\
\text { for financial periods ending } \\
\text { before the IFRS for SMEs was } \\
\text { issued }\end{array}$ & $\begin{array}{c}\text { November } \\
30,2011\end{array}$ & 14 \\
\hline $\begin{array}{l}\text { Draft } \\
\text { Q\&A* } 6\end{array}$ & $\begin{array}{l}\text { September } \\
2011\end{array}$ & $\begin{array}{l}\text { IFRS for SMEs General, Issue } 2 . \\
\text { Interpretation of 'undue cost or } \\
\text { effort' and 'impracticable' }\end{array}$ & $\begin{array}{c}\text { November } \\
30,2011\end{array}$ & 15 \\
\hline $\begin{array}{l}\text { Draft } \\
\text { Q\&A*7 }\end{array}$ & $\begin{array}{l}\text { September } \\
2011\end{array}$ & $\begin{array}{l}\text { IFRS for SMEs Section } 3 \text {, Issue } 1 . \\
\text { Jurisdiction requires fallback to } \\
\text { full IFRS }\end{array}$ & $\begin{array}{c}\text { November } \\
30,2011\end{array}$ & 14 \\
\hline $\begin{array}{l}\text { Draft } \\
\text { Q\&A* } 8\end{array}$ & $\begin{array}{l}\text { September } \\
2011\end{array}$ & $\begin{array}{l}\text { IFRS for SMEs Section 3, Issue } 2 . \\
\text { Departure from a principle in } \\
\text { the IFRS for SMEs }\end{array}$ & $\begin{array}{l}\text { November } \\
30,2011\end{array}$ & 14 \\
\hline $\begin{array}{l}\text { Draft } \\
\text { Q\&A*9 }\end{array}$ & $\begin{array}{l}\text { September } \\
2011\end{array}$ & $\begin{array}{l}\text { IFRS for SMEs Section 3, Issue } 3 \text {. } \\
\text { Prescription of the format of } \\
\text { financial statements by local } \\
\text { regulation }\end{array}$ & $\begin{array}{l}\text { November } \\
30,2011\end{array}$ & 14 \\
\hline $\begin{array}{l}\text { Draft } \\
Q \& A^{*} 10\end{array}$ & $\begin{array}{c}\text { November } \\
2011\end{array}$ & $\begin{array}{l}\text { IFRS for SMEs Section 11, Issue } \\
\text { 1. Fallback to IFRS } 9 \text { Financial } \\
\text { Instruments }\end{array}$ & $\begin{array}{l}\text { January } \\
31,2012\end{array}$ & 13 \\
\hline $\begin{array}{l}\text { Draft } \\
\text { Q\&A*11 }\end{array}$ & $\begin{array}{c}\text { November } \\
2011\end{array}$ & $\begin{array}{l}\text { IFRS for SMEs Section 30, Issue } \\
1 . \quad \text { Recycling of cumulative } \\
\text { exchange differences on disposal } \\
\text { of a subsidiary }\end{array}$ & $\begin{array}{l}\text { January } \\
31,2012\end{array}$ & 12 \\
\hline $\begin{array}{l}\text { Request } \\
\text { for } \\
\text { informa- } \\
\text { tion }\end{array}$ & June 2012 & $\begin{array}{l}\text { Comprehensive Review of the } \\
\text { IFRS for SMEs }\end{array}$ & $\begin{array}{l}\text { November } \\
30,2012\end{array}$ & 82 \\
\hline \multicolumn{4}{|c|}{ Total comment letters analysed } & 615 \\
\hline
\end{tabular}

* Implementation guidance to address certain issues in the form of Questions and Answers(Q\&As). Source: compiled by the authors based on www.ifrs.org

Standish (2003) points out that the traditional influence of English speakers on the Council and in the technical staff of the IASB may condition the participation of other countries in the due process. Burlaud and Colasse (2011) also point out how language can constitute a barrier for participating in the due process. Jorissen et al. (2013) find significant distortions in the geographical distribution of comment let- 
ters due to both differences in local regulations, as well as familiarity with IASB's standards. Larson and Herz (2013), analysing participation between 2001 and 2008 in comment letters addressed to the IASB, show a greater geographical diversity with respect to the former IASC, although still with a high concentration from the European Union (48\%), as well as from the 'G4+1' (46\%). According to this, Molina and Bautista-Mesa (2018) also find that European countries show a higher presence in the IASB's due process between 2004 and 2011. Countries from Asia have traditionally showed the second-largest number of respondents (Huian, 2013).

In general, a greater participation from countries with more developed securities markets is suggested (Larson and Herz, 2013), i.e., countries more affected by the economic consequences of full IFRS in the terms summarised by Zeff (2008). In contrast, Latin America and African countries (Vieira and Borba, 2015) have traditionally exhibited a lower participation. Thus, unlike full IFRS, our research wonders whether a greater participation in the IFRS for SMEs due process comes from regions with higher economic incentives to implement the IFRS for SMEs, i.e., Latin American and African countries. This then leads us to the fourth research question:

RQ.4. Is participation from Latin American and African countries proportionally higher in the due process for the IFRS for SMEs than for full IFRS?

Regarding economic development, UNCTAD has steadily expressed its concern about the difficulties in applying IFRS in developing countries, where capital markets are less relevant, and where the assistance of accounting professionals may not be affordable: '. . . it has often been difficult to apply them to SMEs, particularly those in developing countries and countries with economies in transition. For many businesses in these countries, professional help may also be disproportionately expensive' (UNCTAD, 2003, pg. iii). Then, UNCTAD (2003) argued that a set of standards for SMEs would contribute to the economic development of countries. For this reason, this international organization was a pioneer, through the International Standards of Accounting and Reporting (ISAR), in issuing some simplified accounting guides that would ease financial reporting in developing countries.

A high-quality accounting framework is supposed to enhance a country's credibility in front of international investors (Kaya and Koch, 2014), as well as domestic financial access to credit (Ball et al., 2008; Ball and Shivakumar, 2008), especially for SMEs. Existing research has assessed higher financial constraints for SMEs compared to larger entities in developing countries (Beck and Demirguc-Kunt, 2006). This suggests higher incentives of emerging countries to adopt IFRS for SMEs because of the existence of greater differences between local accounting standards and the IFRS for SMEs (Barth et al., 2008). In order to be competitive in international capital markets, regulators of emerging nations are more willing to take timely measures to harmonize their financial reporting practices with globally accepted financial reporting standards (Klç and Uyar, 2017).

Previous research reveals a lower participation from developing countries in full IFRS due process (Larson and Herz, 2013). However, developed nations have generally ignored the IFRS for SMEs (Klç and Uyar, 2017) because they have their own accounting standards that are closely linked to regulatory and tax purposes (Ball and Shivakumar, 2005). Thus, changing to IFRS for SMEs as the primary set of accounting standards is supposed to be less costly in developing countries (Nobes, 2010). In addition, the relevance of accounting in debt contracting is higher in developing countries due to the absence of public capital markets (Kaya and Koch, 2014). Then, our work questions whether the proportion of constituents from developing countries, i.e., countries with more economic incentives for applying the IFRS for SMEs, is also greater in the IFRS for SMEs due process in comparison to the standards for listed companies. This then leads us to the fifth research question:

RQ.5. Is participation of developing countries proportionally higher in the due process for the IFRS for SMEs than for full IFRS?

\section{Research design}

This section describes the data sources, and the statistical techniques used for comparing stakeholders and measuring the differences in participation between IFRS for SMEs and full IFRS.

Grouping constituents to the IFRS for SMEs: data selection and classification methodology

The study starts out gathering from the IFRS Foundation website all of the documents issued by the IASB, as well as all of the comment letters received related to the IFRS for SMEs, as summarised in Table 1.

Then, constituents are classified according to both their geographic origin and their role in the financial reporting chain, according to IFAC (2008): (i) users, such as investors; (ii) preparers or suppliers of financial information, i.e., those 'economic entities that employ resources in the preparation and presentation of accounting information' (Pina, 1991, pg.107); (iii) auditors; (iv) financial information distributors, such as the media; (v) evaluators, such as analysts and rating agencies; (vi) issuers of advice regarding accounting standards (henceforth named as 'standards setters'); (vii) regulators, mainly public administration, securities market authorities, and central banks; and (viii) consultants, such as investment banks.

This paper slightly modifies the above classification, as it regroups collectives (i), (iv), (v), (vii), and (viii) into the common heading of 'users', considering that their interests about financial information are similar. This heading mainly includes the group of users as 'those individuals that use accounting information directly or indirectly to make economic decisions' (Pina, 1991, pg. 108). 'Regulators' are also included within the group of 'users', as it is commonly accepted that securities commissions usually defend the interests of users (Burlaud and Colasse, 2011), finding also common patterns of responses among the group of regulators and those of users in full IFRS (Giner and Arce, 2012). In addition, we also include 'academics' within this group, as their arguments provide a user approach especially concerned with comparability of financial information and consistency of accounting standards within the conceptual framework (Barth, 2008; Larson et al. 2011; Álvarez et al., 2014).

The geographical variable has been traditionally studied from different perspectives (MacArthur, 1996 and 1999; Larson and Herz, 2013; Jorissen et al., 2013). MacArthur (1996; 1999) finds a relationship between the cultural factors identified by Hofstede $(1980 ; 1983)$ and preferences of preparers, standards setters, and auditors. To achieve this, the author classifies constituents into eight cultural areas (Anglo-Saxon countries, colonial Asia, eastern Africa, the coast of Africa, Germanic countries, the most developed Asian countries, and 
those of more developed Latin as well as Nordic origin). Our research groups constituents geographically in a manner consistent with the 'Criteria for Board members' as set out in the Annex to the IFRS Foundation Constitution, i.e., countries from the Asia/Oceanía region, Europe, the Americas, and Africa (IFRS Foundation, 2016). Our paper slightly modifies this classification separating countries from Latin America and from North America for research purposes. In addition, like in recent studies, our paper deals with one of the main difficulties of geographical classification when allocating international constituents. For auditors, associations or supranational bodies, our study takes as the geographic origin their context of performance (i.e., European or international). In the case of multinational preparers or users, the geographical origin is determined according to their headquarters' location.

In addition, our study places special emphasis on differences in the participation of developing countries in the IFRS for SMEs. To define the level of development, we use the classification by the United Nations Development Program (UNDP) through the Human Development Index (HDI) (PNUD, 2013). This index is based on three national indicators (life expectancy, literacy, and education) to group countries into four categories: very high, high, medium, and low. The first of these categories is used to define the developed countries, while the other three categories include the socalled developing countries. In addition, and in order to identify those countries with the most economic difficulties, within the above classification we segregate those that the UN classifies as the 'countries least developed' (UNCTAD, 2012).

\section{Contrasting groups of stakeholders to the IFRS for SMEs}

Our analysis begins by contrasting the appropriateness of the classification of constituents made in the previous step, according to the role of the individuals in the financial reporting chain.

As our study focuses on the differences between full IFRS and IFRS for SMEs due processes, we only select basic questions that link full IFRS and IFRS for SMEs. Specifically, we choose questions that deal with the coordination mechanisms between the IFRS for SMEs and full IFRS in the 2004 Discussion Paper, obtaining the following independent dichotomous variables:

(i) Variable DP2004.Q4: 'Do you agree that if the IASB regulations for SMEs do not address a particular issue regarding recognition, measurement or revelation, the entity must follow the pertinent IFRS to resolve that particular issue?' (It takes value 1 if yes, and 0 if not).

(ii) Variable DP2004.Q5: 'Should it be permitted to revert to the IFRS if treatment in the version for SMEs differs from treatment in IFRS, or instead, should SMEs choose between the complete set of IFRS and the complete set of standards for SMEs without optional reversion to the IFRS?' (It takes value 1 if yes, and 0 if not).

Like previous research (i.e., Anacoreta and Duarte, 2005; Yen et al., 2007; Hansen, 2011; Stenka and Taylor, 2010; Holder et al., 2013), we use content analysis to classify responses to the questions above. In opposition to quantitative bibliometric methodologies based on the use of counting software, content analysis requires the intervention of an expert, semantically interpreting the responses within the context of the complete letter (Krippendorf, 2013). This type of analysis provides a more reliable quantification of information (Beattie et al., 2004). In total, 121 answers are collected and classified. Like recent research (Jorissen et al., 2013), both the classification of the constituents, as well as the codification of the responses, are carried out following a 'test-retest' methodology conducted independently by two researchers. Results are compared by the two researchers, who come to agreements about any possible differences. In any case, the differences found only amounted to $0.8 \%$, which is statistically irrelevant and confirms the validity of the coding. The differences, once compared, are reviewed by consensus.

Once responses are codified into DP2004.Q4 and DP2004.Q5 variables, we perform cluster analysis to contrast the suitability of predefined groups of constituents. This analysis contrasts every group through a hierarchical cluster model. This technique first deals with each one of the individuals assuming that there is no predetermined number of natural groups, and then groups them according to their similarity until all of the individuals are included in one group (Hair et al., 1999). The hierarchy of the partitions is graphically represented by the dendrogram in Appendix A. Cluster analysis is contrasted by comparing the classification of constituents according to their role in the financial reporting chain (dependent variables) and responses to the DP2004.Q4 and DP2004.Q5a (independent variables).

\section{Measuring the differences between IFRS for SMEs and full IFRS}

Once the classification of constituents has been contrasted, we explore differences between constituents of the IFRS for SMEs and full IFRS due processes. To achieve this, comment letters received from each group and geographical location are compared to other full IFRS projects. Bilateral comparison tests are performed by calculating $\mathrm{Z}$ statistic.

The comparison group is made up of all of the 97 IASB's consultation documents for full IFRS issued between 2004 and 2012 (Appendix B). Data are gathered from 'IFRS Comment Letters Database' elaborated by the Accounting and Financial Economics Department of the Universidad Loyola Andalucía (Spain) from the IASB website as used by Molina and Bautista-Mesa (2018). The selected period (between 2004 and 2012) comprises the period of time when all of the consultation documents for the subsequent IFRS for SMEs were issued.

\section{Results and discussion}

Graphically, the results demonstrate the existence of four groups of stakeholders in the IFRS for SMEs due process, as inferred from the dendrogram (Appendix A). The accuracy of the classification of constituents is confirmed through the 2 statistic $(n=121 ; p=0.001)$ calculated in the contingency test by comparing the resulting classification of the dendrogram with the classification of constituents initially proposed (Table 2). Answering RQ.1, these results confirm the goodness of the classification of constituents into four groups of stakeholders in the case of the IFRS for SMEs.

The relationship between the groups of constituents defined and the independent variables is contrasted through an ANOVA analysis. Results in Table 3 confirm the statistical significance of the relationship between the conglomerates obtained by the cluster analysis with predesigned groups (role) and the responses to the questions used in this analysis. 
Table 2

Contingency analysis for cluster conglomerates $(n=121)$

\begin{tabular}{lrrrrr}
\hline \multirow{2}{*}{ Group (role) } & \multicolumn{3}{c}{ Initial number of cases per conglomerate } & \multirow{2}{*}{ Total } \\
\cline { 2 - 5 } & Preparer & Auditor & $\begin{array}{c}\text { Standards } \\
\text { setter }\end{array}$ & User & \\
\hline Preparer & 12 & 6 & 0 & 3 & 21 \\
Auditor & 1 & 50 & 0 & 0 & 51 \\
Standards & 0 & 0 & 13 & 5 & 18 \\
setter & 0 & 0 & 6 & 25 & 31 \\
User & 0 & & & & \\
\hline
\end{tabular}

Chi-squared $=200.405(\mathrm{p}=0.001)$

Table 3

ANOVA on cluster conglomerates $(n=121)$

\begin{tabular}{lrrrrrr}
\hline \multirow{2}{*}{ Variable } & \multicolumn{2}{c}{ Conglomerate } & \multicolumn{2}{c}{ Error } & & \\
\cline { 2 - 6 } & $\begin{array}{c}\text { Mean } \\
\text { square root }\end{array}$ & df & $\begin{array}{c}\text { Mean } \\
\text { square root }\end{array}$ & df & \multicolumn{1}{c}{ F } & \multicolumn{1}{c}{ Sig. } \\
\hline Group (role) & 44.540 & 3 & .156 & 117 & 285.32 & $.000(* * *)$ \\
& & & & & 1 & .000 \\
DP2004.Q4 & .556 & 3 & .218 & 94 & 2.546 & $.061(*)$ \\
DP2004.Q5 & 3.980 & 3 & .198 & 97 & 20.061 & $.000(* * *)$ \\
\hline
\end{tabular}

Significance levels: ${ }^{*} \mathrm{p}<0.1,{ }^{* *} \mathrm{p}<0.05$, and $* * * \mathrm{p}<0.01$.

Thus, we can conclude that constituents of the IFRS for SMEs can be grouped into four major predefined categories in our study: preparers, auditors, standards setters, and users. These results allow further research based on the fact that stakeholders in the IFRS for SMEs also position themselves according to their own opinions, just as Sutton (1984) proposed for the case of accounting standards related to listed companies.

The results in Table 4 show a clear predominance of auditors $(52,7 \%)$, followed by standards setters $(18,0 \%)$, users $(15,0 \%)$ and, finally, by preparers of financial information $(14,3 \%)$, i.e., SMEs, with the lowest participation.

After comparing these results with full IFRS projects (Table $5)$, a significantly different behaviour of auditors $(z=17.759$; $p<0.01)$ and preparers $(z=-8.777 ; p<0.01)$ is confirmed.

Thus, that the participation of the preparers does not comprise a majority in the case of the IFRS for SMEs and, answering our RQ.2, it is proportionally lower than in full IFRS projects. This implies greater difficulties in the due process of the IASB in order to understand the preferences of SMEs. On the one hand, SMEs may be less aware of the regulatory role of the IASB (Kenny and Larson, 1993). This circumstance is especially relevant in Europe, one of the areas traditionally showing greater participation in the due process, where the greater uncertainty about the application of the IFRS for SMEs and the remoteness of its economic effects may give SMEs less incentive to participate. On the other hand, nonlisted companies are conscious of the limits of their influence (Georgiou, 2005). In addition, participation costs are supposed to be proportionally higher for SMEs than for larger companies. This is why economic incentives for the remission of comment letters, in the cost-benefits terms defined by Sutton (1984), are lower in the case of SMEs. Then, we suggest as a possible cause of the limited international ap-

\section{Table 4}

Classification of comment letters to IFRS for SMEs according the role of the constituent

\begin{tabular}{|c|c|c|c|c|c|c|c|c|c|c|c|c|c|c|c|c|c|}
\hline \multirow[b]{2}{*}{$\begin{array}{l}\text { Constituent's } \\
\text { role }\end{array}$} & \multirow[b]{2}{*}{$\begin{array}{l}\text { ঠे } \\
\text { ठ } \\
\text { ค. } \\
\text { ค. }\end{array}$} & \multirow[b]{2}{*}{ 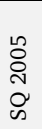 } & \multirow[b]{2}{*}{ 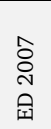 } & \multicolumn{11}{|c|}{ Drafts Q\&A } & \multirow[b]{2}{*}{$\begin{array}{l}\text { Na } \\
\stackrel{\text { N }}{\not 2}\end{array}$} & \multirow[b]{2}{*}{ 忘 } & \multirow[b]{2}{*}{$\%$} \\
\hline & & & & 1 & 2 & 3 & 4 & 5 & 6 & 7 & 8 & 91 & 101 & 11 & & & \\
\hline Preparer & 21 & 18 & 36 & 0 & 0 & 1 & 0 & 0 & 0 & 0 & 0 & 0 & 0 & 0 & 12 & 88 & $14,3 \%$ \\
\hline Auditor & 51 & 47 & 71 & 11 & 8 & 8 & 8 & 121 & 13 & 12 & 12 & 12 & 10 & 9 & 40 & 324 & $52,7 \%$ \\
\hline Standards setter & 18 & 20 & 21 & 5 & 4 & 5 & 4 & 2 & 2 & 2 & 2 & 2 & 3 & 3 & 18 & 111 & $18,0 \%$ \\
\hline User & 31 & 14 & 30 & 0 & 1 & 1 & 3 & 0 & 0 & 0 & 0 & 0 & 0 & 0 & 12 & 92 & $15,0 \%$ \\
\hline Total & 121 & 99 & 158 & 16 & 13 & 15 & 15 & 14 & 15 & 14 & 14 & 14 & 131 & 12 & 82 & 615 & $100,0 \%$ \\
\hline
\end{tabular}

Table 5

Comparison of comment letters to IFRS for SMEs and full IFRS

\begin{tabular}{lrrr}
\hline \multirow{2}{*}{ Constituent's role } & \multicolumn{2}{c}{ Number of comment letters } & \multirow{2}{*}{ Z statistic } \\
\cline { 2 - 3 } & IFRS for SMEs & Full IFRS & \\
\hline Preparer & 88 & 3.644 & $-8,777(* * *)$ \\
Auditor & 324 & 2.550 & $17,759(* * *)$ \\
Standards setter & 111 & 1.571 & $3,315(* * *)$ \\
Bank and insurance & 7 & 2.047 & $-10,354(* * *)$ \\
User & 85 & 1.752 & -0.711 \\
Unknown & 0 & 203 & $-3,203(* * *)$ \\
\hline Total & 615 & 11.767 & \\
\hline
\end{tabular}

Significance levels: ${ }^{*} \mathrm{p}<0.1,{ }^{* *} \mathrm{p}<0.05$, and $* * * \mathrm{p}<0.01$

${ }^{1}$ For this analysis, we separate the banking and insurance collective because, although it is considered largely to adopt a users role with respect to financial information in the case of the IFRS for SMEs, this is not as evident in the case of full IFRS for listed companies (Mora and Molina, 2014).

plication of the IFRS for SMEs not only the need for further analysis regarding the real needs of users of financial information for SMEs (Di Pietra et al., 2008; Haveroth et al., 2017), but also the lack of analysis of preparers' preferences.

The results also show a proportionally higher participation of auditors (RQ.3). This greater participation was expected according to the greater dispersion of auditors for SMEs when compared to the concentration of auditors for listed companies. This suggests that SMEs have a tendency to leave their representation in the due process to the auditor due to the cost-benefit reasons that this participation entails for them, in line with Walker and Robinson (1993) and Georgiou (2002). However, it is important to point out that the group of preparers is independent to auditors, as stated in the previous cluster analysis. Using arguments more related to the quality of the standards of financial information than to a simplification of requirements for preparers, auditors do not seem to assume in this case the representation of their clients' interests. Contrary to previous research for the case of listed companies, these results suggest that the incentives of SMEs' auditors are not necessarily in conjunction with the interests of their clients, but are influenced by auditing risk and stability, like defined by Meier et al. (1993).

In addition, results reveal a greater involvement by local standards setters $(z=3,315 ; p<0.01)$, as well as a significantly lower participation by bank and insurance entities $(z=-$ 10.354; $p<0.01)$. Regarding the latter, previous research expected the IFRS for SMEs to improve the opportunities of SMEs to obtain assistance from the banking sector (Berger and Udell, 2004; Allee and Yohn, 2009; Klç and Uyar, 2014). The reduced participation of banks and insurance entities in the IFRS for SMEs due process would call into question that statement, supporting the idea that the IFRS for SMEs may fail regarding the specific needs of SMEs' creditors, who are traditionally more concerned with the ability to generate cash flow (FASB, 2013).

From a geographical point of view, the results in Appendix $\mathrm{C}$ show that the greatest number of comment letters to the IFRS for SMEs comes from Europe (43\%), in accordance with previous research for full IFRS (Larson and Herz, 2013; Haveroth et al., 2017). However, this rate is lower in the case of the IFRS for SMEs. A greater presence of AngloSaxon countries, the United Kingdom and Ireland (13\%), is also found. This is in line with previous research that identifies the United Kingdom and Ireland as the most significant supporters of the IFRS for SMEs, due to their smaller link between accounting data and other regulatory and tax requirements (Kaya and Koch, 2014).

Asia is the second most represented region (15\%), with a high proportion of letters from only three groups, also of 
Anglo-Saxon tradition: Hong Kong, Malaysia, and Singapore. The proportion of roles within this region also shows a high concentration in only two groups, auditors (47.83\%) and standards setters (36.96\%). There is little presence of preparers and users of financial information. The results also confirm the low level of interest that international regulation holds for SMEs in North America (4\%). Furthermore, while in the case of full IFRS the participation of the former ' $\mathrm{G} 4+1$ ' is relevant given its influence in the IASB reform in 2001 (Jorissen et al., 2013), the case of the IFRS for SMEs is less pronounced. Thus, constituents from the former ' $\mathrm{G} 4+1$ ' represent only $17 \%$ against $34 \%$ in full IFRS projects.

Results in Table 6 reveal a proportionally greater concern from Latin American $(z=7.544 ; p<0.01)$ and African $(z=7.977 ; p<0.01)$ jurisdictions, which are historically far from the IASB tradition, less familiar with the English language, and with a lower degree of development (RQ.4).

Table 6

Comparison of the geographical origin of constituents

\begin{tabular}{lrrc}
\hline \multirow{2}{*}{ Region } & \multicolumn{2}{c}{ Number of comment letters } & \\
\cline { 2 - 3 } & IFRS for SMEs & Full IFRS & \\
\hline International & 108 & 1.101 & $6.700(* * *)$ \\
Africa & 54 & 347 & $7.977(* * *)$ \\
Asia & 118 & 2.199 & 0.329 \\
Europe & 270 & 5.091 & 0.266 \\
Latin America & 33 & 168 & $7.544(* * *)$ \\
North America & 30 & 2.762 & $-10.744(* * *)$ \\
Unknown & 2 & 99 & -1.385 \\
\hline Total & 615 & 11.767 & \\
\hline Significance levels: ${ }^{*} \mathrm{p}<0.1,{ }^{*} \mathrm{p}<0.05$, and & $* * \mathrm{p}<0.01$. & \\
\hline
\end{tabular}

Delving deeper into the development level (RQ.5), the results (Table 7) show a greater concern from developing countries $(z=8.247 ; p<0.01)$, in contrast to the reduced participation in full IFRS projects. In line with Klç and Uyar (2017), stakeholders perceive that a set of financial information standards of quality for unlisted companies is very relevant for the economic development of less developed regions. We suggest two reasons for this: (i) the greater relevance of unlisted companies in the economy, given the less developed capital markets; and (ii) the lack of resources in developing economies to issue their own standards for SMEs or to establish differential reporting frameworks (Devi and Samujh, 2015).

Table 7

Comparison of comment letters in terms of development level

\begin{tabular}{|c|c|c|c|}
\hline & \multicolumn{2}{|c|}{ Number of comment letters } & \multirow{2}{*}{ Z statistic } \\
\hline & IFRS for SMEs & Full IFRS & \\
\hline Developed countries & 324 & 8.854 & $-12.454(* * *)$ \\
\hline Developing countries & 123 & 1.139 & $8.247(* * *)$ \\
\hline Being "less developed countries" & 19 & 69 & $7.204(* * *)$ \\
\hline Supranational or undetermined ${ }^{\mathrm{i}}$ & 168 & 1.774 & $8.138(* * *)$ \\
\hline Total & 615 & 11.767 & \\
\hline
\end{tabular}

${ }^{\mathrm{i}}$ Not available for this analysis because the letters are supranational or of undetermined origin.

\section{Conclusions}

As a first contribution, our paper demonstrates for the first time that stakeholders in the accounting regulation for SMEs also position themselves following their own interest, like demonstrated for listed companies (Sutton, 1984), according to the Economic Theory of Democracy. This is especially relevant, taking into consideration the singularities of the accounting regulatory framework for SMEs recognized by the IASB: (i) a lower capability of preparers; and (ii) the existence of differences in the nature of 'external users' of financial information.

Regarding the singularity of preparers, our research states that the participation of preparers in international accounting standardisation for SMEs is significantly lower than in the case of standards for listed companies. Results reveal that this lower participation is substituted by a higher involvement of auditors. However, unlike previous research on full IFRS, our results suggest that smaller auditors do not represent the interest of their clients in the due process, forming an independent group of opinion in the case of IFRS for SMEs. Both effects contribute to undermine the representation of SMEs in the international accounting regulation process.

Some of the reasons explaining the lower participation of SMEs can be inferred from previous research for listed companies: (i) SMEs may not be aware of the IASB's due process, as some of them are too small to know about the existence of the IFRS foundation and its activity; (ii) SMEs have fewer resources to enable participation in the due process; (iii) SMEs may have the perception that their influence on the standards setter is limited; and (iv) there may be great uncertainty about the application of the standard, especially in the early stages of its drafting.

IASB (2016) argues that 95\% of the entities around the world are electable for the IFRS for SMEs to justify the economic relevance of the standard. However, the lower involvement of SMEs in the regulation process supports the idea that this computation includes a very large number of microentities without international relevance that are not motivated, in terms of the Economic Theory of Democracy, by the possible benefits of a globally single accounting standard for SMEs.

Regarding the singularities of 'external users' of SMEs, our research also contributes to question whether the IASB fails regarding the specific needs of users of SMEs' accounting information, who are traditionally more concerned with the ability to generate cash flow. Traditionally, there has been criticism about the lack of users' involvement in IASB's projects. The European Union, a jurisdiction that has not yet accepted the use of IFRS for SMEs, warns about the need to carry out a more detailed analysis of the specific needs of users of financial information under the IFRS for SMEs. We also suggest the lack of user representation. In particular, our research reveals a significantly low involvement by banks and a proportionally high participation by local standards setters in the issuance process of the IFRS for SMEs. Although the IFRS for SMEs provides a cash flow statement, our results may support the assertion that the Government is, in general, the main user of the financial statements of the SMEs, while other users may be skeptical about the reliability of SMEs' accounting information.

From a geographical perspective, we suggest the relevance of increasing the quality of financial information standards in developing countries, in accordance with the pronouncements of UNCTAD (2003) and findings by previous research (i.e., Klç and Uyar, 2017). Although participation in the IFRS for SMEs due process is still concentrated in developed countries, especially from Europe, our results demonstrate that there is a higher implication from developing and less developed countries. In terms of the Economic Theory of Democracy, these countries would possess greater incentives to ad- 
opt a global single accounting standard for SMEs to enhance their capabilities in international capital and trade markets. Unlike developed countries, the differences between their local accounting standards and the IFRS for SMEs are high, and thus the benefits of changing their local GAAP would exceed its costs. In particular, despite historical language and accounting tradition barriers, the greater incentives of developing economies move Latin American and African countries to a higher involvement in the IFRS for SMEs.

In summary, the IASB seems to fail in applying the same due process for full IFRS to gain input legitimacy in the IFRS for SMEs. This way of 'mimetic isomorphism' represents a limitation of the Institutional Theory (Meyer and Rowan, 1977) for the IASB. This may contribute to the reluctance of certain jurisdictions to implement the IFRS for SMEs.

The pertinent question is whether an international standard, such as the IFRS for SMEs, aimed at protecting the user, is the most appropriate for a large number of SMEs without an international presence and, especially, in certain countries with less developed capital markets. Some opinions still consider the IFRS for SMEs to be too complex, even in the most developed countries (European Commission, 2010). Other opinions also point out the lack of attention to managerial and legal burdens of SMEs. Alternative guides (ISAR) produced by UNCTAD for smaller SMEs (level 3) may better respond to the needs for simplification for preparers with few resources, since they have been developed with a bottom-up approach, based on the real preferences of users and preparers of the smallest entities (UNCTAD, 2008). While ISAR prioritised the production of information that is also useful for SME management, this objective was postponed by the IASB in the case of the IFRS for SMEs. ISAR also prioritised the application of the historical cost, as well as a simplified accrual system, as very close to a cash basis.

As an implication of our research, IASB should improve mechanisms to gather the preferences of SMEs. It could be necessary, in this standard more than any other, to engender a greater involvement of other stakeholders, such as academics, because the rigor derived from their independence and methodology could represent a timely contribution to the regulatory process (Barth, 2007 and 2011; Abela and Mora, 2012). This conclusion is in line with UNCTAD, which is still concerned about SMEs, wondering if their real needs for financial information are satisfied by the IFRS for SMEs, and suggesting new changes for the future (UNCTAD, 2013).

The international standardisation led by the IASB is an example of the growing trend to transfer certain regulatory processes into the hands of supranational organisations. As in the case of financial reporting standards, regulation in other areas that may potentially affect the economics of SMEs could be entrusted to international technocratic institutions. Our research also warns about the difficulties of SMEs to influence, not only IASB, but other international institutions in a new globalised economic context.

\section{Acknowledgements}

An earlier version of this article benefited from the presentation at the ' $\mathrm{V}$ Taller de Investigación en Contabilidad' held in Sevilla (Spain) in June 2013, and the 'XVII Congreso AECA' held in Pamplona (Spain) in September 2013. We would like to thank the Department of Accountancy and Finance of Universidad Loyola Andalucía and especially Prof. Dr. Horacio Molina and Prof. Dr. Jesús N. Ramírez for their support and very helpful comments. Additionally, we thank the anonymous referees and the editor for their extensive constructive feedback on the paper. None of these individuals bears responsibility for any of the views expressed here. This work is part of the research group 'SEJ-425 - Information to enhance business competitiveness' of the Andalusian Government (Spain).

\section{Conflict of interests}

The authors declare no conflict of interests.

\section{References}

Abela, M., \& Mora, A. (2012). Understanding the consequences of Accounting Standards in Europe: The Role of EFRAG. Accounting in Europe, 9(2), 147-170.

Allen, A., Ramanna, K., \& Roychowdhury, S. (2012). The auditing oligopoly and lobbying on accounting standards. Harvard Business School Working Papers, 13-054.

Albu, C.N., Albu, N., \& Fekete, S. (2010). The context of the possible IFRS for SMEs implementation in Romania: An exploratory study. Accounting and Management Information Systems, 9(1), 45-71.

Allee, K.D., \& Yohn, T.L. (2009). The Demand for Financial Statements in an Unregulated Environment: An Examination of the Production and Use of Financial Statements by Privately Held Small Businesses. Accounting Review, 84(1), 1-25.

Álvarez, I., Calvo, J.A., \& Mora, A. (2014). Involving academics in the accounting standard setting process: an application of the Delphi methodology to the assessment of IASB proposals. Journal of Management and Governance, 18(3), 765-791.

Anacoreta L., \& Duarte, P. (2005). International Accounting Standards for SME's: an exploratory study. Doctoral dissertation, Universidade Católica Portuguesa.

Ball, R. (2006). International financial reporting standards (IFRS): Pros and cons for investors. Accounting and Business Research, 5(27), 5-27.

Ball, R., \& Shivakumar, L. (2005). Earnings quality in private UK firms: comparative loss recognition timeliness. Journal of Accounting and Economics, 39(1), 83-128.

Ball, R., \& Shivakumar, L. (2008). How much new information is there in earnings?. Journal of Accounting Research, 46(5), 957-1016.

Ball, R., Robin, A, \& Sadka, G. (2008). Is Financial Reporting Shaped by Equity Markets or by Debt Markets?. An International Study of Timeliness and Conservatism. Review of Accounting Studies, 13(2-3), 168-205.

Ballas, A.A., Skoutela, D., \& Tzovas, C.A. (2010). The relevance of IFRS to an emerging market: evidence from Greece. Managerial Finance, 36(11), 931-948.

Barth, M.E. (2007). Research, standard setting and global financial reporting. Foundations and Trends in Accounting, 1(2), 71-165.

Barth, M.E. (2008). Global Financial Reporting: Implications for US academics. Accounting Review, 83(5), 11591179.

Barth, M.E. (2011). Financial Accounting, Research, standard setting and Practice: The quest for a missing link?. Symposium at EAA Congress, Rome-Siena.

Barth, M.E., Landsman, W.R., \& Lang, M.H. (2008). International accounting standards and accounting quality. Journal of Accounting Research, 46 (3), 467-498.

Beattie, V., McInnes, B., \& Fearnley, S. (2004). A methodology for analyzing and evaluating narratives in annual 
reports: A comprehensive descriptive profile and metrics for disclosure quality attributes. Accounting Forum, 28(3), 205236.

Beck, T., \& Demirguc-Kunt, A. (2006). Small and mediumsize enterprises: Access to finance as a growth constraint, Journal of Banking and Finance, 30(11), 2931-2943

Becker, G. S. (1983). A theory of competition among pressure groups for political influence. The quarterly journal of economics, 98(3), 371-400.

Berger, A.N., \& Udell, G.F. (2004). A More Complete Conceptual Framework for PYME Finance. Policy Research Working Paper Series 3795, The World Bank.

Bonito, A., \& Pais, C. (2018). The macroeconomic determinants of the adoption of IFRS for SMEs, Revista de Contabilidad-Spanish Accounting Review, 21(2), 116-127.

Burlaud, A., \& Colasse, B. (2011). International accounting standardisation: is politics back?. Accounting in Europe, 8 (1), 23-47.

Carmo, C.H.S., Ribeiro, A.M., \& Carvalho, L.N.G. (2014). Influência dos grupos de interesse no proceso de normatização contábil internacional: o caso do Discussion Paper sobre Leasing. Contabilidade Vista \& Revista, 25(2), 98-118.

Chand, P., Patel, A., \& White, M. (2015). Adopting International Financial Reporting Standards for Small and Mediumsized Enterprises. Australian Accounting Review, 25(2), 139-154.

Chircop, J \& Kiosse, P.V. (2015). Why did preparers lobby to the IASB's pension accounting proposals?. Accounting Forum, 39, 268-280.

Dhaliwal, D.S. (1982). Some Economic Determinants of Management Lobbying for Alternative Methods of Accounting: Evidence from the Accounting for Interests Costs Issue. Journal of Business Finance \& Accounting, 9 (2), 255-265.

Devi, S.S., \& Samujh, H. (2015). The Political Economy of Convergence: The Case of IFRS for SMEs. Australian Accounting Review, 25(2), 124-138.

Di Pietra, R., Evans, L., Checy, J, Cisi, M., Eierle, B., \& Jarvis, R. (2008). Comment on the IASB's Exposure Draft 'IFRS for Small and Medium-Sized Entities. Accounting in Europe, 5 (1), 27-46.

DiMaggio, P.W., \& Powell, W.W. (1983). The iron cage revisited: Institutional isomorphism and collective rationality in organisational fields. American Sociology Review, 48 (2), 147-160.

Durocher, S., Fortin, A., \& Côte, L. (2007). Users' participation in the accounting standard-setting process: A theorybuilding study. Accounting, Organizations and Society, 32, 29-59.

Eierle, B., Haller, A., \& Beiersdorf, K. (2011). IFRS for SMEs - eine 'attraktive' Alternative für nicht kapitalmarktorientierte Unternehmen in Deutschland? Der Betrieb, 64 (29), 1589-1596.

European Commission (2010). Summary report on the responses received to the Commission's consultation on the International Financial Reporting Standard for Small and Medium-sized Entities. Available from http://ec.europa.eu/internal_market/accounting/docs/ ifrs/2010-05-31_ifrs_sme_consultation_summary_en.pdf [accessed August, 29, 2016].

European Commission (2011). Study on Accounting requirements for PYMEs, Available from http://ec.europa. eu/enterprise/policies/pyme/business-environment/files/ study_on_accounting_requirements for pymes final report en.pdf [accessed August, 29, 2016].

Financial Accounting Standards Board (FASB) (2013). Private Company Decision-Making Framework. A
Guide for Evaluating Financial Accounting and Reporting for Private Companies. Available from https: //www.fasb.org/jsp/FASB/Document_C/DocumentPage? cid $=1176163703583$ \&acceptedDisclaimer $=$ true $\quad$ [accessed August, 29, 2016].

Francis, J.R. (1987). Lobbying Against Proposed Accounting Standards: The Case of Employers' Pension Accounting, Journal of Accounting and Public Policy, 6(1), 35-57.

Georgiou, G. (2002). Corporate non-participation in the ASB standard-setting process. European Accounting Review, 11(4), 699-722.

Georgiou, G. (2005). Investigating Corporate Management Lobbying in the UK Accounting Standards-Setting Process: A Multi-Issue/Multi-Period Approach. Abacus, 41(3), 323-347.

Giner, B., \& Arce, M. (2012). Lobbying on Accounting Standards: Evidence from IFRS 2 on Share-Based Payments. European Accounting Review, 21(4), 655-691.

Hair, J.F., Anderson, R.E., Tatham, R.L., \& Black, W.C. (1999). Análisis Multivariante (5ł Edición). Madrid: Prentice Hall.

Hansen, T.B. (2011). Lobbying of the IASB: An Empirical Investigation. Journal of International Accounting Research, 10(2), 57-75.

Haring, J.R. (1979). Accounting rules and "The accounting stablishment". Journal of Business, 52(4), 507-519.

Hartwig, F. (2013). Preparers and Non-preparers Lobbying on the Proposed Prohibition of Goodwill Amortisation in ED3 Business Combinations. The Finnish Journal of Business Economics, 63(3-4), 30-60.

Haveroth, J., De Nez, E., Bilk, Â., \& Klann, R.C. (2017). Characteristics and International Perspectives of Different Stakeholder Groups in IFRS for SMEs. Revista De Educação E Pesquisa Em Contabilidade, 11(4), 418-437.

Hofstede, G. (1980). Culture's Consequences: International Differences in Work-Related Values. Beverly Hills, CA: Sage Publications.

Hofstede, G. (1983). Dimensions of national cultures in fifty countries and three regions. In Deregowski, J.B., Dziurawiec, S., \& Annis, R.C., (eds). Expiscations in cross-cultural psychology, Lisse: Swets and Zeitlinger, 335-355.

Holder, A.D., Karim, K.E., Lin, K.J., \& Woods, M. (2013). A content analysis of the comment letters to the FASB and IASB: Accounting for contingencies. Advances in Accounting, incorporating Advances in International Accounting, 29, 134-153.

Huian, M.C. (2013). Stakeholders' participation in the development of the new accounting rules regarding the impairment of financial assets. Business Management Dynamics, 2(9), 23-35

IFRS Foundation (2013a). Constitution. Revised and approved by the Trustees. January 2013. Available from http://www.ifrs.org/The-organisation/ Governance-and-accountability/Constitution/Documents/ IFRS-Foundation-Constitution-January-2013.pdf [accessed August, 29, 2016].

IFRS Foundation (2013b). Due process Handbook. Approved by the Trustees. January 2013. Available from http://www.ifrs.org/DPOC/Documents/2013/Due Process_Handbook Resupply_28_Feb_2013_WEBSITE.pdf [accesse-d August, 29, 2016].

IFRS Foundation (2016). Constitution. Revised and approved by the Trustees. January 2013. Available from https://www.ifrs.org/-/media/feature/ about-us/legal-and-governance/constitution-docs/ 
ifrs-foundation-constitution.pdf [accessed November, $11,2018]$.

Internal Market and Services DG (2010). Framework Contract for projects relating to Evaluation and Impact Assespyment activities of Directorate General for Internal Market and Services. 4th Company Law Directive and IFRS for PYMEs. Final Report, Available from http://ec.europa.eu/internal_market/accounting/docs/ studies/2010_cses_4th_company_law_directve_en.pdf

[accessed Novemberer, 1, 2013]

International Accounting Standards Board (IASB). (2009a). International Financial Reporting Standards (IFRS) for Small and Medium Sized Entities (SME). Available from http://www.ifrs.org/ifrs-for-smes/Pages/ifrs-for-smes.aspx [accessed November, 11, 2018]

International Accounting Standards Board (IASB). (2009b). International Financial Reporting Standards (IFRS) for small and medium sized entities (SME): Basis of conclusion. Available from http: / /www.ifrs.org/ifrs-for-smes/Pages/ifrs-forsmes.aspx [accessed November, 11, 2018]

International Accounting Standards Board (IASB) (2018). Analysis of the IFRS profiles for the IFRS for SMEs Standard. Available from: https://www.ifrs.org/use-around-the-world/ use-of-ifrs-standards-by-jurisdiction/\#analysis [accessed November, 11, 2018)

International Federation of Accountants (IFAC) (2008). Financial Reporting Supply Chain. Current Perspectives and Directions. Available from http://www.ifac.org/sites/default/files/publications/

files/financial-reporting-supply.pdf [accessed August, 29, 2016].

Jensen, M., \& Meckling, W.H. (1976). Theory of the firm: managerial behaviour, agency costs and ownership structure. Journal of Financial Economics, 3 (4), 305-360.

Jorissen, A., Lybaert, N., \& Van de Poel, K. (2006). Lobbying towards a global standard setter-do national characteristics matter?: an analysis of the comment letters written to the IASB, in: Gregoriou, G.N., \& Gaber, M., eds. International accounting: standards, regulations, and financial reporting, Oxford: Elsevier, 1-39.

Jorissen, A., Lybaert, N., Orens, R., \& Van Der Tas, L. (2010). Formal Participation in the IASB's Due Process of Standard Setting: A Multi-Issue/Multi-Period Analysis. European Accounting Review, 21(4), 693-729.

Jorissen, A., Lybaert, N., Orens, R., \& Van Der Tas, L. (2013). A geographic analysis of constituents' formal participation in the process of international accounting standard setting: Do we have a level playing field?. Journal of Accounting and Public Policy, 32, 237-270.

Kaya, D., \& Koch, M. (2014). Countries' adoption of the International Financial Reporting Standard for Small and Mediumsized Entities (IFRS for SMEs) - early empirical evidence. Accounting and Business Research, 45(1), 93-120.

Kelly, L. (1985). Corporate Management Lobbying on FAS No. 8: Some Further Evidence. Journal of Accounting Research, 23(2), 619-632.

Kenny, S., \& Larson, R.K. (1993). Lobbying behaviour and the development of international accounting standards: the case of the IASC's joint venture project. European Accounting Review, 2(3), 283-301.

Klç, M., Uyar, A., \& Ataman, B. (2014). Preparedness for and perception of IFRS for SMEs: Evidence from Turkey. Accounting and Management Information Systems, 13(3), 492-
519.

Klç, M., \& Uyar, A. (2017). Adoption process of IFRS for SMEs in Turkey: insights from academics and accountants. Journal Of Accounting \& Management Information Systems: JAMIS, 16(2), 313-339.

Kim, J.B., Tsui, J.S.L., \& Yi, C.H. (2011). The voluntary adoption of international reporting standards and loan contracting around the world. Review of Accounting Studies, 16(4), 779-811.

Krippendorff, K. (2013). Content Analysis. An Introduction to Its Methodology. Thousand Oaks, CA: SAGE Publications, Inc.

Larson, R.K., Herz, P.J., \& Kenny, S.Y. (2011). Academics and the Development of IFRS: An Invitation to Participate. Journal of International Accounting Research, 10(2), 97-103.

Larson, R.K., \& Herz, P.J. (2013). A Multi-Issue/MultiPeriodAnalysis of the Geographic Diversity of IASB Comment Letter Participation. Accounting in Europe, 10 (1), 99-151.

Lindahl, F.W. (1987). Accounting Standards and Olson's Theory of Collective Action. Journal of Accounting and Public Policy, 6(1), 59-72.

MacArthur, J.B. (1996). An Investigation into the influence of Cultural Factors in the International Lobbying of the International Accounting Standards Committee: The Case of E32, Comparability of Financial Statements. International Journal of Accounting, 31(2), 213-237.

MacArthur, J.B. (1999). The Impact of Cultural Factors on the Lobbying of the International Accounting Standards Committee on E32, Comparability of Financial Statements: An extension of MacArthur to Accounting Member Bodies. Journal of International Accounting, Auditing and Taxation, 8(2), 315-335.

MacKee, A.J., Williams, P.F., \& Frazier, K.B. (1991). A Case Study of Accounting Firm Lobbying: Advice or Consent. Critical Perspectives on Accounting, 2, 273-294.

Meier, H., Alam, P., Pearson, M. (1993). Auditor lobbying for accounting standards: the case of banks and savings and loan associations. Accounting and Business Research, 23(92), 477-487.

Meyer, J.W., \& Rowan, B. (1977). Institutionalized Organizations: Formal Structure as Myth and Ceremony. American Journal of Sociology, 83 (2), 340-363.

Milanés, P., \& Texeira, J. (2006). Evaluación de la utilidad de la información financiera elaborada por la pequeña empresa: un estudio empírico. Revista de ContabilidadSpanish Accounting Review, 9 (17), 81-98.

Molina, H., \& Bautista-Mesa, R. (2018). La participación en el due process del IASB. Estudios de Economía Aplicada, 36(2), 429-458.

Moneva, J.M., \& Cuéllar, B. (1999). Utilidad de la información financiera obligatoria para la gestión: Análisis de la PYME española. Revista de Contabilidad-Spanish Accounting Review, 2(4), 137-159.

Mora, A., \& Molina, H. (2014). Lobbying on the accounting standard setting: the case of the leasing project. X Workshop de Contabilidad Empírica, La Coruña.

Nobes, C. (2010). On researching into the use of IFRS by private entities in Europe. Accounting in Europe, 7(2), 213226.

Olson, M. (1965). The Logic of Collective Action, Cambridge: Harvard University.

Pacter, P. (2009). An IFRS for private entities. International Journal of Disclosure and Governance, 6(1), 4-20.

Perera, D., \& Chand, P. (2015) Issues in the adoption of international financial reporting standards (IFRS) for small and medium-sized enterprises (SMES). Advances in Accounting, 
incorporating Advances in International Accounting, 31(1), 165-178.

Pina, V. (1991). Investigación Empírica y Normalización Contable. Revista Española de Financiación y Contabilidad, 21(66), 83-126.

Programa de las Naciones Unidas para el Desarrollo (PNUD) (2013). Informe sobre Desarrollo Humano 2013. Available from http://www.undp.org/content/dam/ undp/library/corporate/HDR/2013GlobalHDR/Spanish/

HDR2013\%20Report\%20Spanish.pdf [accessed August, 29, 2016].

Puro, M. (1984). Audit firm lobbying before the Financial Accounting Standards Board: an empirical study. Journal of Accounting Research, 22(2), 624-646.

Puro, M. (1985). Do Large Accounting Firms Collude in the Standard Setting Process?. Journal of Accounting, Auditing and Finance, 8(3), 165-177.

Richardson, A.J., \& Eberlein, B. (2011). Legitimating Transnational Standard-setting: The Case of The International Accounting Standards Board. Journal of Business Ethics, 98, 217-245.

Schiebel, A. (2008). Is there a solid empirical foundation for the IASB's draft IFRS for SMEs?, Working Paper, Vienna University of Economics and Business Administration. Available from http://ssrn.com/abstract=994684 [accessed August, 29, 2016].

Seamann, G. (2004). Positions taken in the FASB and IASB Due Processes on Accounting for Employee Stock Options. Journal of Accounting \& Finance Research, 12(2), 1-5.

Son, D.D., Marriott, N., \& Marriott, P. (2006). Users' perceptions and uses of financial reports of small and medium companies (SMCs) in transitional economies: Qualitative evidence from Vietnam. Qualitative Research in Accounting and Management, 3(3), 218-235.

Standish, P. (2003). Evaluating national capacity for direct participation in international accounting harmonization: France as a test case. Abacus, 39(2), 186-210.

Stenka, R.I., \& Taylor, P. (2010). Setting UK Standards on the Concept of Control: An Analysis of Lobbying Behaviour. Accounting and Business Research, 40(2), 109-130.

Sutton, T.G. (1984). Lobbying of accounting standardsetting bodies in the U.K. and the U.S.A.: a Downsian analysis. Accounting, Organizations and Society, 9(1), 81-95.

Tandy, P.R., \& Wilburn, N.L. (1996). The academic community's participation in standard setting: submission of comment letters on SFAS Nos. 1-117. Accounting Horizons, 10(3), 92-111.

United Nations Conference on Trade and Development (UNCTAD), (2003). Accounting and Financial Reporting Guidelines for Small and Medium-sized Enterprises (SMEGA). Level 2 Guidance. Available from http:// unctad.org/en/docs/iteteb20035_en.pdf [accessed August, 29, 2016].

United Nations Conference on Trade and Development (UNCTAD) (2008). Accounting and Financial Reporting GUidelines for Small and Medium-sized Enterprises (SMEGA). Level 3 Guidance. Available from http://unctad. org/en/docs/c2isard50_en.pdf [accessed August, 29, 2016].

United Nations Conference on Trade and Development (UNCTAD) (2012). The Least Developed Countries Report 2012. Available from http://unctad.org/en/ PublicationsLibrary/ldc2012_en.pdf [accessed August, 29, 2016].

United Nations Conference on Trade and Development (UNCTAD) (2013). Opening remarks by Tatiana Krylova, Head, Enterprise Branch, UNCTAD. Joint UNCTAD-ISAR and IFRS Foundation workshop on Accounting by SMEs. Available from http://unctad.org/en/PublicationsLibrary/ 1dc2012 en.pdf [accessed August, 29, 2016].

Vasek, L. (2011). IFRS for SMEs a new challenge for worldwide financial reporting. International Journal of Management Cases, Special Issue, 115-120 [accessed August, 29, 2016].

Vieira, R.T., \& Borba, J.A. (2015) Análise do processo de revisão pós-implementação do IFRS 08 por meio das cartas comentários enviadas por empresas. Revista de Contabilidade e Controladoria, 7(1), 64-80.

Watts, R., \& Zimmerman, J. (1978). Towards A Positive Theory of the Determination of Accounting Standards. Accounting Review, 53 (1), 112-134.

Walker, R.G., \& Robinson, P. (1993). A critical assessment of the literature on political activity and accounting regulation. Research in Accounting Regulation, 7, 3-40.

Yen, A.C., Hirst, D.E., \& Hopkins, P.E. (2007). A content analysis of the comprehensive income exposure draft comment letters. Research in Accounting Regulation, 19, 53-79.

Zeff, S.A. (2008). Political Lobbying on Accounting Standards -US, UK and International Experience, en: Nobes, C., \& Parker, R., eds. Comparative International Accounting (IX edition), Essex: Pearson Education Limited, 206-234. 
Appendix A. Dendrogam
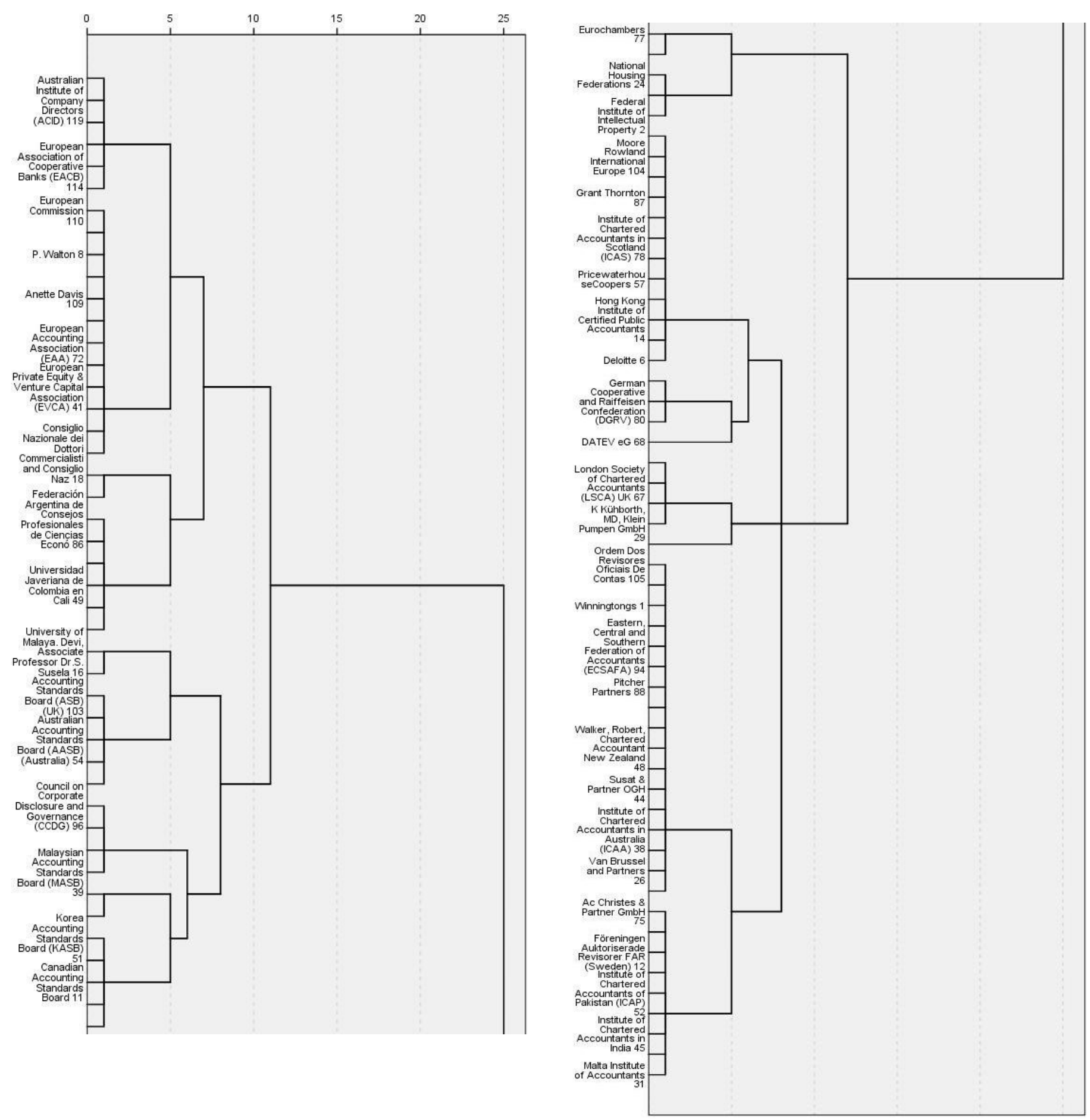
Appendix B. IASB's full IFRS due process documents (comparison group) ${ }^{1}$

\begin{tabular}{|c|c|c|c|}
\hline $\begin{array}{c}\text { Type of } \\
\text { document }\end{array}$ & $\begin{array}{c}\text { Year of } \\
\text { issuance }\end{array}$ & Description & $\begin{array}{c}\text { Number of } \\
\text { comment letters }\end{array}$ \\
\hline Exposure draft & 2004 & Amendments to IAS 39 Financial Instruments: Cash Flow Hedge Accounting of Forecast Intra Group Transactions & 58 \\
\hline Exposure draft & 2004 & Amendments to IAS 39. Recognition, Measurement and IFRS 4 Insurance Contracts & 61 \\
\hline Exposure draft & 2004 & Exploration for and Evaluation of Mineral Resources & 60 \\
\hline Exposure draft & 2004 & Financial Instruments Disclosures & 106 \\
\hline Exposure draft & 2004 & IAS 19 Employee Benefits-Actuarial Gains and Losses, Group Plans and Disclosures 2004 & 92 \\
\hline Exposure draft & 2004 & IFRS 3 Business Combinations 2004 & 75 \\
\hline Exposure draft & 2004 & $\begin{array}{l}\text { Proposed Amendments to IAS } 39 \text { Financial Instruments: Recognition and Measurement: The Fair Value Option } \\
\text { Proposed Amendments to IAS } 39 \text { Financial Instruments: }\end{array}$ & 116 \\
\hline Exposure draft & 2004 & $\begin{array}{l}\text { Recognition and Measurement: Transition and Initial Recognition of Financial } \\
\text { Assets and Financial Liabilities }\end{array}$ & 37 \\
\hline Exposure draft & 2005 & Amendments to IFRS 3 Business Combinations & 282 \\
\hline Discussion paper & 2005 & Management Commentary & 112 \\
\hline Discussion paper & 2005 & Measurement Bases for Financial Accounting & 86 \\
\hline Exposure draft & 2005 & Memorandum of Understanding on the role of Accounting Standard-Setters and their Relationships with the IASB & 67 \\
\hline Exposure draft & 2005 & Proposed Amendments to IAS 27. Consolidated and Separate Financial Statements & 94 \\
\hline Exposure draft & 2005 & Proposed Amendments to IAS 37 Provisions, Contingent Liabilities and Contingent Assets and IAS 19 Employee Benefits & 121 \\
\hline Exposure draft & 2006 & Amendments to Financial Statements & 128 \\
\hline Exposure draft & 2006 & $\begin{array}{l}\text { Amendments to IAS } 32 \text { Financial Instruments: Presentation and IAS } 1 \text { Presentation of Financial Statements Financial Instruments Puttable at Fair } \\
\text { Value and Obligations Arising on Liquidation }\end{array}$ & 88 \\
\hline Discussion paper & 2006 & Conceptual Framework Objectives and Qualitative Characteristics & 179 \\
\hline Exposure draft & 2006 & IAS 23 Borrowing Costs & 90 \\
\hline Exposure draft & 2006 & Operating Segments & 181 \\
\hline Exposure draft & 2007 & Amendments to IAS 24. Related Party Disclosures. State-controlled Entities and the Definition of a Related Party & 72 \\
\hline Exposure draft & 2007 & Amendments to IAS 39. Financial Instruments: Recognition and Measurement Exposures Qualifying for Hedge Accounting & 74 \\
\hline Discussion paper & 2007 & Fair Value Measurements & 130 \\
\hline Exposure draft & 2007 & Improvements to International Financial Reporting Standards & 75 \\
\hline Exposure draft & 2007 & Joint Arrangements & 112 \\
\hline Discussion paper & 2007 & Preliminary Views on Insurance Contracts & 158 \\
\hline Exposure draft & 2008 & Additional Exceptions to IFRS 1 & 95 \\
\hline Exposure draft & 2008 & Amendments Improving Disclosures about Financial Instruments & 89 \\
\hline Exposure draft & 2008 & $\begin{array}{l}\text { Amendments to IFRS } 1 \text { First-time Adoption of International Financial Reporting Standards and IAS } 27 \text { Consolidated and Separate Financial } \\
\text { Statements Cost of an Investment in a Subsidiary, Jointly Controlled Entity or Associate }\end{array}$ & 64 \\
\hline Exposure draft & 2008 & Amendments to IFRS 2 Share-based Payments and IFRIC 11 & 43 \\
\hline Exposure draft & 2008 & An Improved Conceptual Framework for Financial Reporting: Chapters 1 and 2 & 143 \\
\hline Exposure draft & 2008 & Consolidated Financial Statements & 151 \\
\hline Preliminary views & 2008 & Constitution Review Part 2 & 68 \\
\hline Exposure draft & 2008 & Discontinued Operations. Proposed Amendments to IFRS 5 & 62 \\
\hline Exposure draft & 2008 & Embedded Derivatives. Proposed Amendments to IFRIC 9 and IAS 39 & 58 \\
\hline Discussion paper & 2008 & Equity and Liability & 123 \\
\hline Discussion paper & 2008 & Financial Statements Presentation & 228 \\
\hline Discussion paper & 2008 & Preliminary Views Amendments to IAS 19 Employee Benefits & 148 \\
\hline Discussion paper & 2008 & Preliminary Views on an Improved Conceptual framework. The Reporting Entity & 84 \\
\hline Discussion paper & 2008 & Reducing Complexity in Financial Instruments & 160 \\
\hline Exposure draft & 2008 & Relationships with the State. Proposed Amendments to IAS 24 & 75 \\
\hline Exposure draft & 2008 & Simplifying Earnings per Share. Proposed Amendments to IAS 33 & 58 \\
\hline Exposure draft & 2009 & Classification of Rights Issues. Proposed Amendments to IAS 32 & 45 \\
\hline Discussion paper & 2009 & Credit Risk in Liability Measurement & 122 \\
\hline Exposure draft & 2009 & Derecognition & 118 \\
\hline Exposure draft & 2009 & Discount Rate for Employee Benefits. Proposed Amendments to IAS 19 & 105 \\
\hline Request for information & 2009 & Expected Loss Model & 89 \\
\hline Exposure draft & 2009 & Fair Value Measurements & 160 \\
\hline Exposure draft & 2009 & Financial Instruments: Amortised Cost and Impairment & 190 \\
\hline Exposure draft & 2009 & Financial Instruments: Classification and Measurement & 242 \\
\hline Exposure draft & 2009 & Improvements & 72 \\
\hline Exposure draft & 2009 & Income Tax & 164 \\
\hline Exposure draft & 2009 & Investments in Debt Instruments. Proposed Amendments to IFRS 7 & 91 \\
\hline Discussion paper & 2009 & Leases & 302 \\
\hline Exposure draft & 2009 & Limited Exemption from Comparative IFRS 7 Disclosures for First-time Adopters. Proposed Amendment to IFRS 1 & 22 \\
\hline Exposure draft & 2009 & Management Commentary & 99 \\
\hline Preliminary views & 2009 & Proposals for Enhanced Public Accountability. Part 2 of the Constitution Review & 67 \\
\hline Exposure draft & 2009 & Rate-regulated Activities & 156 \\
\hline Discussion paper & 2009 & Revenue Recognition & 223 \\
\hline Consultation document & 2010 & Annual Improvements & 34 \\
\hline Exposure draft & 2010 & Conceptual Framework for Financial Reporting. The Reporting Entity & 114 \\
\hline Exposure draft & 2010 & Deferred Tax: Recovery of Underlying Assets. Proposed Amendments to IAS 12 & 75 \\
\hline Exposure draft & 2010 & Defined Benefit Plans. Proposed Amendments to IAS 19 & 226 \\
\hline Discussion paper & 2010 & Extractive Industries & 144 \\
\hline Exposure draft & 2010 & Fair Value Option for Financial Liabilities & 136 \\
\hline Exposure draft & 2010 & Hedge Accounting & 242 \\
\hline Exposure draft & 2010 & Leases & 774 \\
\hline Exposure draft & 2010 & Measurement of Liabilities & 209 \\
\hline Exposure draft & 2010 & Measurement Uncertainty Analysis. Disclosure for Fair Value Measurements. Limited Re-exposure of Proposed Disclosure & 91 \\
\hline Exposure draft & 2010 & Insurance Contracts & 247 \\
\hline Exposure draft & 2010 & Presentation of Items of Other Comprehensive Income. Proposed Amendments to IAS 1 & 143 \\
\hline Exposure draft & 2010 & Removal of Fixed Dates for First-time Adopters. Proposed Amendments to IFRS 1 & 38 \\
\hline Exposure draft & 2010 & Revenues Recognition & 686 \\
\hline Exposure draft & 2010 & Severe Hyperinflation & 34 \\
\hline Preliminary views & 2010 & Status of the Trustees' Strategy Review & 95 \\
\hline Exposure draft & 2011 & Financial Instruments Impairments & 212 \\
\hline Preliminary views & 2011 & IFRSs as the Global Standard: Setting a Strategy for the Foundation's Second Decade & 74 \\
\hline Exposure draft & 2011 & Improvements & 67 \\
\hline Exposure draft & 2011 & Investment Entities & 168 \\
\hline Exposure draft & 2011 & Mandatory Effective Dates of IFRS 9 & 131 \\
\hline Exposure draft & 2011 & Offsetting Financial Assets and Liabilities & 161 \\
\hline Exposure Draft & 2011 & Revenues Recognition & 355 \\
\hline Exposure Draft & 2012 & Acquisition of an Interest in a Joint Operation & 70 \\
\hline Exposure Draft & 2012 & Annual Improvements Cycle 2010-2012 & 82 \\
\hline Exposure Draft & 2012 & Annual Improvements Cycle 2011-2013 & 65 \\
\hline Exposure draft & 2012 & Clarification of Acceptable Methods of Depreciation and Amortisation & 98 \\
\hline Exposure draft & 2012 & Classification and Measurement. Limited Amendments to IFRS 9 & 166 \\
\hline Exposure draft & 2012 & Drafting Constitution Review & 18 \\
\hline Exposure draft & 2012 & Equity Method: Share of Other Net Asset Changes & 77 \\
\hline Exposure draft & 2012 & Government Loans. Proposed Amendments to IFRS 1 & 39 \\
\hline Request for information & 2012 & Post-implementation Review: IFRS 8 Operating Segments & 62 \\
\hline Exposure draft & 2012 & Transition Guidance. Proposed Amendments to IFRS 10 & 64 \\
\hline \multicolumn{3}{|l|}{ Total } & 11.767 \\
\hline
\end{tabular}

${ }^{1}$ From the Comment Letters Database by the Accounting and Financial Economy Department in Universidad Loyola Andalucía (Spain). 
Appendix C. Geographical distribution of comment letters to IASB's due process for IFRS for SMEs

\begin{tabular}{|c|c|c|c|c|c|c|c|c|c|c|c|c|c|c|c|}
\hline Region & ఫे & $\stackrel{2}{8}$ & $\hat{8}$ & & & & & DRA & TS Q & & & & & & $\stackrel{\text { ก }}{1}$ \\
\hline COUNTRY & 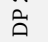 & O & 空 & 1 & 2 & 3 & 4 & 5 & 6 & 7 & 8 & 9 & 10 & 11 & జ \\
\hline INTERNATIONAL & 10 & 9 & 14 & 5 & 4 & 4 & 4 & 7 & 8 & 7 & 7 & 7 & 6 & 5 & 11 \\
\hline AFRICA & 7 & 6 & 12 & 1 & 2 & 2 & 2 & 2 & 2 & 2 & 2 & 2 & 1 & 1 & 10 \\
\hline AFRICA (comprehensive) & 1 & & 1 & & & & & & & & & & & & \\
\hline CAMEROON & & 1 & 1 & & & & & & & & & & & & \\
\hline KENYA & & 1 & 1 & & & & & & & & & & & & 1 \\
\hline MALAWI & 1 & & 1 & & & & & & & & & & & & \\
\hline MOZAMBIQUE & 2 & & & & & & & & & & & & & & \\
\hline RWANDA & & & & & & & & 1 & 1 & 1 & 1 & 1 & & & 1 \\
\hline SOUTH AFRICA & 2 & 4 & 5 & 1 & 1 & 1 & 1 & 1 & 1 & 1 & 1 & 1 & 1 & 1 & 5 \\
\hline TANZANIA & & & 1 & & & & & & & & & & & & \\
\hline TUNISIA & & & 1 & & & & & & & & & & & & \\
\hline UGANDA & & & & & & & & & & & & & & & 2 \\
\hline ZAMBIA & 1 & & 1 & & 1 & 1 & 1 & & & & & & & & 1 \\
\hline ASIA & 11 & 14 & 22 & 6 & 3 & 3 & 3 & 2 & 2 & 2 & 2 & 2 & 3 & 3 & 12 \\
\hline ASIA (comprehensive) & & 1 & 2 & & & & & & & & & & & & 1 \\
\hline CHINA & & 1 & & & & & & & & & & & & & \\
\hline DUBAI & & & 1 & & & & & & & & & & & & \\
\hline FIJI & & & 1 & & & & & & & & & & & & \\
\hline HONG KONG & 1 & 1 & 3 & 1 & 1 & 1 & 1 & 1 & 1 & 1 & 1 & 1 & 1 & 1 & 1 \\
\hline INDIA & 1 & 1 & 2 & 2 & & & & & & & & & & & 2 \\
\hline INDONESIA & & & 1 & & & & & & & & & & & & \\
\hline IRAN & & & 1 & & & & & & & & & & & & \\
\hline ISRAEL & 1 & 1 & 1 & & & & & & & & & & & & 2 \\
\hline JAPAN & 3 & 3 & 2 & & & & & & & & & & & & 1 \\
\hline MALAYSIA & 2 & 3 & 1 & 1 & 1 & 1 & 1 & & & & & & 1 & 1 & 1 \\
\hline PAQUISTAN & 1 & 1 & 2 & 1 & & & & & & & & & & & 1 \\
\hline SINGAPORE & 1 & 1 & & 1 & 1 & 1 & 1 & 1 & 1 & 1 & 1 & 1 & 1 & 1 & 1 \\
\hline SOUTH KOREA & 1 & 1 & 3 & & & & & & & & & & & & 1 \\
\hline SRI LANKA & & & & & & & & & & & & & & & 1 \\
\hline THAILAND & & & 1 & & & & & & & & & & & & \\
\hline THE PHILIPPINES & & & 1 & & & & & & & & & & & & \\
\hline EUROPE & 69 & 50 & 78 & 4 & 3 & 5 & 5 & 3 & 3 & 3 & 3 & 3 & 3 & 3 & 37 \\
\hline EUROPE (comprehensive) & 13 & 12 & 8 & 1 & 1 & 1 & 1 & 1 & 1 & 1 & 1 & 1 & 1 & 1 & 5 \\
\hline AUSTRIA & 1 & 1 & 4 & & & & & & & & & & & & \\
\hline BELGIUM & 3 & & & & & & & & & & & & & & \\
\hline BULGARIA & 1 & & & & & & & & & & & & & & \\
\hline CZECH REPUBLIC & & 1 & 1 & & & & & & & & & & & & \\
\hline DENMARK & 1 & 2 & 2 & & & & & & & & & & & & \\
\hline ESTONIA & & & & & & & & & & & & & & & 1 \\
\hline FINLAND & 1 & 1 & 2 & & & & & & & & & & & & \\
\hline FRANCE & 2 & 4 & 9 & & & & & & & & & & & & 2 \\
\hline GERMANY & 13 & 10 & 16 & & & & & & & & & & & & 8 \\
\hline GREECE & 1 & & & & & & & & & & & & & & \\
\hline IRELAND & 1 & & 3 & 1 & 1 & 1 & 1 & 1 & 1 & 1 & 1 & 1 & 1 & 1 & 1 \\
\hline ITALY & 3 & 3 & 7 & & & & & & & & & & & & \\
\hline MALTA & 1 & & & & & & & & & & & & & & \\
\hline NORWAY & 1 & 1 & 2 & & & & & & & & & & & & 1 \\
\hline NETHERLANDS & 1 & 2 & 3 & 1 & & & & & & & & & & & 2 \\
\hline PORTUGAL & 1 & 1 & & & & & & & & & & & & & \\
\hline ROMANIA & 1 & & & & & & & & & & & & & & 1 \\
\hline RUSSIA & & 2 & 2 & & & & & & & & & & & & \\
\hline SPAIN & 1 & 1 & 2 & & & & & & & & & & & & 3 \\
\hline SWEDEN & 3 & 2 & 1 & & & & & & & & & & & & \\
\hline SWITZERLAND & 2 & 1 & & & & & & & & & & & & & 2 \\
\hline THE VATICAN & 1 & & & & & & & & & & & & & & \\
\hline TURKEY & & & & & & 1 & & & & & & & & & \\
\hline UNITED KINGDOM & 17 & 6 & 16 & 1 & 1 & 2 & 3 & 1 & 1 & 1 & 1 & 1 & 1 & 1 & 11 \\
\hline LATIN AMERICA AND CENTRAL & & & & & & & & & & & & & & & \\
\hline AMERICA & 6 & 6 & 13 & & 1 & 1 & 1 & & & & & & & & 6 \\
\hline $\begin{array}{l}\text { LATIN AMERICA } \\
\text { (comprehensive) }\end{array}$ & & 1 & 2 & & & & & & & & & & & & \\
\hline ARGENTINA & 2 & 1 & 1 & & & & & & & & & & & & 1 \\
\hline BARBADOS & & & 1 & & & & & & & & & & & & \\
\hline BRAZIL & 1 & 1 & 1 & & 1 & 1 & 1 & & & & & & & & 1 \\
\hline COLOMBIA & 2 & & 2 & & & & & & & & & & & & \\
\hline COSTA RICA & 1 & 1 & 1 & & & & & & & & & & & & \\
\hline ECUADOR & & & 1 & & & & & & & & & & & & 1 \\
\hline EL SALVADOR & & & 1 & & & & & & & & & & & & 1 \\
\hline JAMAICA & & & 1 & & & & & & & & & & & & \\
\hline TRINIDAD AND TOBAGO & & 1 & & & & & & & & & & & & & \\
\hline URUGUAY & & 1 & 1 & & & & & & & & & & & & \\
\hline VENEZUELA & & & 1 & & & & & & & & & & & & 1 \\
\hline NORTH AMERICA & 5 & 7 & 11 & & & & & & & & & & & & 3 \\
\hline CANADA & 2 & 1 & 3 & & & & & & & & & & & & \\
\hline MEXICO & 1 & 1 & 1 & & & & & & & & & & & & \\
\hline USA & 2 & 5 & 7 & & & & & & & & & & & & 3 \\
\hline OCEANIA & 12 & 6 & 8 & & & & & & & & & & & & 3 \\
\hline AUSTRALIA & 8 & 3 & 7 & & & & & & & & & & & & 2 \\
\hline NEW ZEALAND & 4 & 3 & 1 & & & & & & & & & & & & 1 \\
\hline UNKNOWN & 1 & 1 & & & & & & & & & & & & & \\
\hline & 12 & & 15 & & & & & & & & & & & & \\
\hline TOTAL & 1 & 99 & 8 & 16 & 13 & 15 & 15 & 14 & 15 & 14 & 14 & 14 & 13 & 12 & 82 \\
\hline
\end{tabular}

